\title{
Comparative performance of six carbon footprint models for use in Ireland
}

\author{
Environmental Impact Assessment Review \\ Volume 29, Issue 1, January 2009, Pages 1-6
}

T. Kenny, N.F. GrayCorresponding author contact information, E-mail the corresponding author

Centre for the Environment, School of Natural Sciences, Trinity College, University of Dublin, Dublin 2, Ireland

Abstract

Carbon footprint models are increasingly being used to manage personal and household carbon dioxide emissions. Six models were compared for their suitability for use in Ireland using typical data for a household of three people. The annual household energy and transportation emissions ranged from 10,540 to $17,361 \mathrm{~kg} \mathrm{CO} 2 \mathrm{yr}-1$ (mean 12,886; sd 2135) rising to a total footprint of 12,053 to 27, $218 \mathrm{~kg} \mathrm{CO} 2 \mathrm{yr}-1$ (mean 18,117; sd 5106) when aviation emissions were included. This represents a potential range for individual CO2 emissions of between 4018 and $9073 \mathrm{~kg} \mathrm{CO2/person/annum,} \mathrm{a} \mathrm{variation} \mathrm{of} \mathrm{over} 5$ tonnes/person. The information provided by these models proved to be inconsistent and often contradictory. The high variability between models was due to a number of anomalies. When these were corrected mean household energy and transportation emissions fell to 12,130 kg CO2 yr- 1 (sd 805), with a total household footprint of 16,552 kg CO2 yr- 1 (sd 1101). Models vary in their complexity in terms of what is included in the overall estimation of emissions making a full analysis of the primary carbon footprint very difficult. When compared to current Irish conversion factors the corrected models either underestimated or overestimated CO2 emissions by approximately $10 \%$. Current carbon footprint models excluded emissions from $\mathrm{CH} 4$ and $\mathrm{N} 2 \mathrm{O}$ underestimating CO2 emissions for the household by $1.8 \%$.

\section{Keywords}

Carbon dioxide; Emissions; Footprint; Household; Model

\section{Introduction}

\subsection{Climate change}

It is now widely accepted that increasing atmospheric concentrations of greenhouse gases (GHGs) are responsible for increasing global temperatures that has resulted in the phenomenon known as climate change (IPCC, 2007). The Intergovernmental Panel on Climate Change (IPCC) have indicated that the risk 
of severe climate change impacts will increase markedly with a temperature increase of $2{ }^{\circ} \mathrm{C}$ above pre-industrial levels (EPA, 2006). The current rate of global temperature increase is between 0.2 and $0.3^{\circ} \mathrm{C} /$ decade (EPA, 2006). However, for there to be a high degree of certainty that the global temperature increase will be limited to $2^{\circ} \mathrm{C} \mathrm{CO} 2$ equivalent (CO2e) concentrations will have to be stabilised at levels of between 400 and 450 ppm CO2e (CEC, 2005, Meinshausen, 2005, EPA, 2006 and Bows et al., 2006). The current level is 430 ppm CO2e and is rising by more than 2 ppm/annum (Stern, 2006). Delaying action to stabilise $\mathrm{CO} 2 \mathrm{e}$ concentration levels will require increasingly greater action in the future to achieve the temperature threshold of $2{ }^{\circ} \mathrm{C}$ (EPA, 2006, Bows et al., 2006, Stern, 2006 and EPA, 2007a).

It is widely believed that it is possible to reduce $\mathrm{CO} 2$ emissions sufficiently to achieve the $2{ }^{\circ} \mathrm{C}$ target without destabilising the global economy by rapidly implementing strong deliberate policy choices (Stern, 2006). Three elements of policy are required for an effective global response: (i) The pricing of carbon, implemented through tax, trading or regulation; (ii) The support of innovation and the deployment of low carbon technologies; and (iii) The removal of barriers to energy efficiency, and to inform, educate and persuade individuals about what they can do to respond to climate change (Stern, 2006). For these policies to be effective then an accurate and equitable method of calculating household and personal CO2e emissions is required.

\subsection{Carbon footprints}

A carbon footprint is a measure of an individual's contribution to global warming in terms of the amount of greenhouse gases produced by an individual and is measured in units of carbon dioxide equivalent (Lynas, 2007). It is made up of the sum of two parts, the direct or primary footprint is a measure of our direct emissions of CO2e from the burning of fossil fuels including domestic energy consumption and transportation (e.g. car and plane); and the indirect or secondary footprint is a measure of the indirect $\mathrm{CO2e}$ emissions from the whole lifecycle of products and services we use including those associated with their manufacture and eventual breakdown (Tukker and Jansen, 2006).

There is increasing awareness of an individual's behaviour or life style as a source of global carbon emissions (Bin and Dowlatabadi, 2005). The calculation of individual and household carbon footprints is a powerful tool enabling individuals to quantify their own carbon dioxide emissions and link these to activities and behaviour. Such models play an important role in educating the public in the management and reduction of $\mathrm{CO} 2$ emissions through selfassessment and determination. Carbon emission models may possibly be used in the future as a tool to calculate carbon taxes, the allocation of carbon units and the basis for personal carbon trading (O'Donoghue, 1997). 


\section{Methods}

\subsection{Model selection}

Carbon footprint models or calculators are widely available on the Internet. Existing models calculate the individual or household primary footprint by converting the amount of electricity, oil, gas or coal used per year into CO2 emissions. They also convert the number of kilometres driven in a car, kilometres on various types of public transport and air kilometres to $\mathrm{CO} 2$ emissions. Models or calculators are provided by a range of organizations including government agencies, non-governmental organizations (NGOs) and private companies. There are no standards or codes of practice associated with these models leading to potentially significant differences and inconsistencies between them.

Six models were selected for comparison on the basis of: (i) Complexity and relevance. Models had to include as many household sources of $\mathrm{CO} 2$ as possible, and the calculation methods had to be household rather than business orientated. (ii) Reliability. The model had to be developed by an expert team or organization. (iii) Recommendation. Models had to be recommended by either a Government Department or a State Energy or Environment Agency. The models selected are generally country specific as is the UK based models Carbon Footprint (http://www.carbonfootprint.com/calculator.html), Resurgence (http://www.resurgence.org/carboncalculator/), the US based Carbon Fund model (http://www.carbonfund.org/site/pages/carbon_calculators/) and the Irish based models Safe Climate (http://www.safeclimate.net/calculator/) and Grian (http://ww2.grian.ie/calculator/onceCalculation.asp). Only the final model selected and Combat Climate Change (http://www.combatclimatechange.ie/index.asp?locID=4), allows a specific country, including Ireland, to be selected within the model.

The Carbon Footprint model uses the UK's Department for the Environment, Food and Rural Affairs (Defra) metrics for its on-line carbon footprint model. Upon examination of the conversion factors the home heating and transport factors are sourced from Defra (2005) fuel conversion factors, which are based on the National Atmospheric Emissions Inventory for 2003 and the UK Greenhouse Gas Inventory for 2003. These conversion factors have been superseded by two Defra reports published in June 2007 (Defra, 2007a and Defra, 2007b). The separate flight emissions model states it is based on the Defra (2007b) guidelines but when flights are calculated they do not concur. Defra, 2007a and Defra, 2007b are sourced from UK Greenhouse Gas Inventory for 2005 (Defra, 2007c) and Digest of UK Energy Statistics (DTI) (Dukes, 2006). 
Resurgence is an English Magazine that has been covering subjects such as ecology, sustainability, art and nature for the last 40 years. Sources of the conversion factors include The National Energy Foundation (NEF), Defra, and the National Office of Statistics. The NEF emissions are based upon information from Defra dating back to 1999 and 2001. The car emissions of $223 \mathrm{~g} \mathrm{CO} 2 /$ passenger $\mathrm{km}$ are based on an average family car returning $29 \mathrm{mpg}(6.38 \mathrm{~km} \mathrm{l-1})$ These emissions equate to those of petrol or diesel cars greater than $2 \mathrm{l}$ in the Defra (2007a) guidelines and exceed the average emissions indicated for this engine size. This site also states that burning wood is not carbon neutral due to a 25year time lag from the release of carbon dioxide stored in the wood by burning to the absorption by a new tree and therefore $50 \%$ of the emissions are included. Flight emissions of $180 \mathrm{~g} \mathrm{CO} 2 /$ passenger km are for short-haul flights in economy class and are multiplied by a factor of 3 to take account of the effects of radiative forcing from condensation trails and nitrogen oxide emissions.

However, the level of scientific understanding of the radiative forcing of contrails and the impacts of non-CO2 emissions from aviation are low (IPCC, 2007 and Forster et al., 2006). They are not addressed in the IPCC 2006 Guidelines for calculating GHG emissions.

The UK models, Carbon Footprint and Resurgence, agree only on emissions from electricity and natural gas. According to Defra (2007a) data, both underestimate natural gas emissions; Carbon Footprint over estimates public transport and flight emissions whereas Resurgence underestimates bus emissions and over estimates car and flight emissions. Carbon Fund uses information from the US Department of Energy's Energy Information Agency, which details American fuel emission coefficients. This site offers the lowest flight emission factors.

The Safe Climate model is supported by the World Resource Institute (2007) and is based on information from the GHG Protocol website. The GHG Protocol site states all calculation tools have been peer-reviewed and tested by experts and industry leaders and represent a best practice for emission calculation tools but does not give further information as to the source of the emission factors. The emissions from oil, flights and electricity in particular are high in comparison to the other sites. It is a US based model with an option to select one's country of residence. Ireland was selected in the home energy usage section but there is no country selection option in the transport section.

The Combat Climate Change and Grian models were selected because they are widely recommended on Irish websites. The Combat Climate Change is a website that is supported by the Irish governmental agency Sustainable Energy Ireland (SEI) and is based on the World Resources Institute's Safe Climate model. However, the emission factors of these two sites do not correlate. The Grian model does not indicate where the emission factors were sourced; what is immediately noticeable is the extremely high emission factor for natural gas. of the sites that relate to Ireland, Safe Climate, Combat Climate Change and Grian, 
none of the emission factors are the same for any fuel type or mode of transport, which is most likely due to the use of different transport emission models.

\subsection{Model evaluation}

Average household size in Ireland has been rapidly declining in recent years. The 2006 census recorded Ireland's population as 4,239,848 with $97.3 \%$ living in $1,469,521$ private households giving an average occupancy rate of 2.81 (CSO, 2007). Therefore, the performance of the six models was compared by entering in data for a typical Irish household of three. This included household energy comprising electricity usage of $4500 \mathrm{kWh} \mathrm{y}-1$, with natural gas central heating and water heating equivalent to $20,000 \mathrm{kWh} y-1$. Transportation comprises of two family cars a $1.4 \mathrm{l}$ petrol (equivalent to $40 \mathrm{mpg}$ ) and $1.8 \mathrm{l}$ diesel (equivalent to $36 \mathrm{mpg}$ ) each driven 15,000 and $16,000 \mathrm{~km} \mathrm{y}-1$ respectively. Total air travel of 27,000 passenger km on short-haul travel were also included. The models were finally compared using Irish conversion factors calculated from the most recent national fuel mixes and net calorific values.

\section{Results and discussion}

\subsection{Comparison of model inputs}

The models were compared in detail in terms of emission sources, conversion factors (Table 1) and how this relates to the specific requirements of users in Ireland. 


\begin{tabular}{|c|c|c|c|c|c|c|c|}
\hline \multirow[t]{5}{*}{ Household } & \multirow[t]{5}{*}{ Units } & Carbon & \multirow[t]{2}{*}{ Resurgence } & Carbon & \multirow[t]{2}{*}{ Safe Climate } & Combat & \multirow[t]{2}{*}{ Grian } \\
\hline & & Footprint & & Fund & & Climate & \\
\hline & & & & & & Change & \\
\hline & & con. factor & con. factor & con. factor & con. factor & con. factor to & con. factor \\
\hline & & to $\mathrm{kg} \mathrm{CO}_{2}$ & to $\mathrm{kg} \mathrm{CO} 2$ & to $\mathrm{kg} \mathrm{CO}_{2}$ & to $\mathrm{kg} \mathrm{CO} \mathrm{CO}_{2}$ & $\mathrm{~kg} \mathrm{CO} 2$ & to $\mathrm{kg} \mathrm{CO}_{2}$ \\
\hline $\begin{array}{l}\text { Number of } \\
\text { occupants }\end{array}$ & & Yes & Yes & Yes & Yes & Yes & Yes \\
\hline $\begin{array}{l}\text { Selection by } \\
\text { country }\end{array}$ & & $\begin{array}{l}\text { No (UK } \\
\text { based) }\end{array}$ & $\begin{array}{l}\text { No (UK } \\
\text { based) }\end{array}$ & $\begin{array}{l}\text { No (USA } \\
\text { based) }\end{array}$ & Yes & $\begin{array}{l}\text { No (Ireland } \\
\text { based) }\end{array}$ & Yes \\
\hline Electricity & kWh & 0.430 & 0.430 & 0.610 & 0.710 & 0.660 & 0.670 \\
\hline Natural gas & kWh & 0.190 & 0.190 & 0.200 & 0.190 & 0.198 & 0.425 \\
\hline LPG & 1 & 1.490 & 1.510 & $x$ & 1.540 & 1.545 & $x$ \\
\hline LPG & kg & $x$ & $x$ & $x$ & $x$ & $x$ & 2.237 \\
\hline Butane & 1 & $x$ & 1.510 & $x$ & $x$ & $x$ & $x$ \\
\hline Butane & kg & $x$ & $x$ & $x$ & $x$ & 3.149 & $x$ \\
\hline Propane & 1 & $x$ & 1.510 & $x$ & 1.510 & $x$ & $x$ \\
\hline Propane & $\mathrm{kg}$ & $x$ & $x$ & $x$ & $x$ & 3.149 & 2.933 \\
\hline Oil & 1 & 2.690 & 2.680 & 2.680 & 3.120 & 2.645 & $x$ \\
\hline Kerosene & 1 & $x$ & $x$ & $x$ & $x$ & 2.486 & $x$ \\
\hline Coal & $\mathrm{kg}$ & 2.550 & 2.410 & $x$ & 2.470 & 2.630 & $x$ \\
\hline Turf & kg & $x$ & $x$ & $x$ & $x$ & 1.362 & $x$ \\
\hline Briquettes & bale & $x$ & $x$ & $x$ & $x$ & 1.829 & $x$ \\
\hline Wood & $\mathrm{kg}$ & $x$ & 0.518 & $x$ & $x$ & $x$ & $x$ \\
\hline $\begin{array}{l}\text { Electricity from } \\
\text { renewables }\end{array}$ & kg & 0.000 & $x$ & $x$ & 0.000 & $x$ & $x$ \\
\hline
\end{tabular}

Carbon Fund, Safe Climate and Grian are limited on the emission factors provided for home heating fuel. For example Carbon Fund does not include LPG while Grain only offers a conversion based on weight used (kg), the others use conversion factors based only on volume (l). Butane is widely used for household heating and cooking in Ireland but only two models offered conversion factors, one using volume and the other by weight. Four out of the six models included propane, although again half based conversions on weight the others on volume. In practice household gas cylinders are sold in standard sizes based on weight not volume making inputting data into the model difficult for average users. While all models included electricity and natural gas, only five included oil, one kerosene, four coal with no differentiation between types, and only the Combat Climate Change model included peat, which is commonly used in Ireland either raw (turf) or milled (briquettes). Only Resurgence had a value for wood, the others apparently considering it carbon neutral (Table 1). In terms of heating 
fuels Combat Climate Change offered the widest choice of options although wood products were excluded.

Carbon Fund, Safe Climate and Combat Climate Change do not offer any emission factors for public transport (Table 2). Car emission values vary widely between the two UK models with Resurgence not differentiating between engine size. Grian's car emissions are calculated per litre of fuel. Neither system appears to take into account either fuel efficiency or the drive cycle of the vehicle. The public transport figures are high in comparison to the other models except for light rail (Luas) where the emission factor is indicated as zero? Combat Climate Change does not put forward any emission factors resulting from flying, with significant variation in conversion factors used by the other models for domestic, short, medium and long haul flights (Table 3).

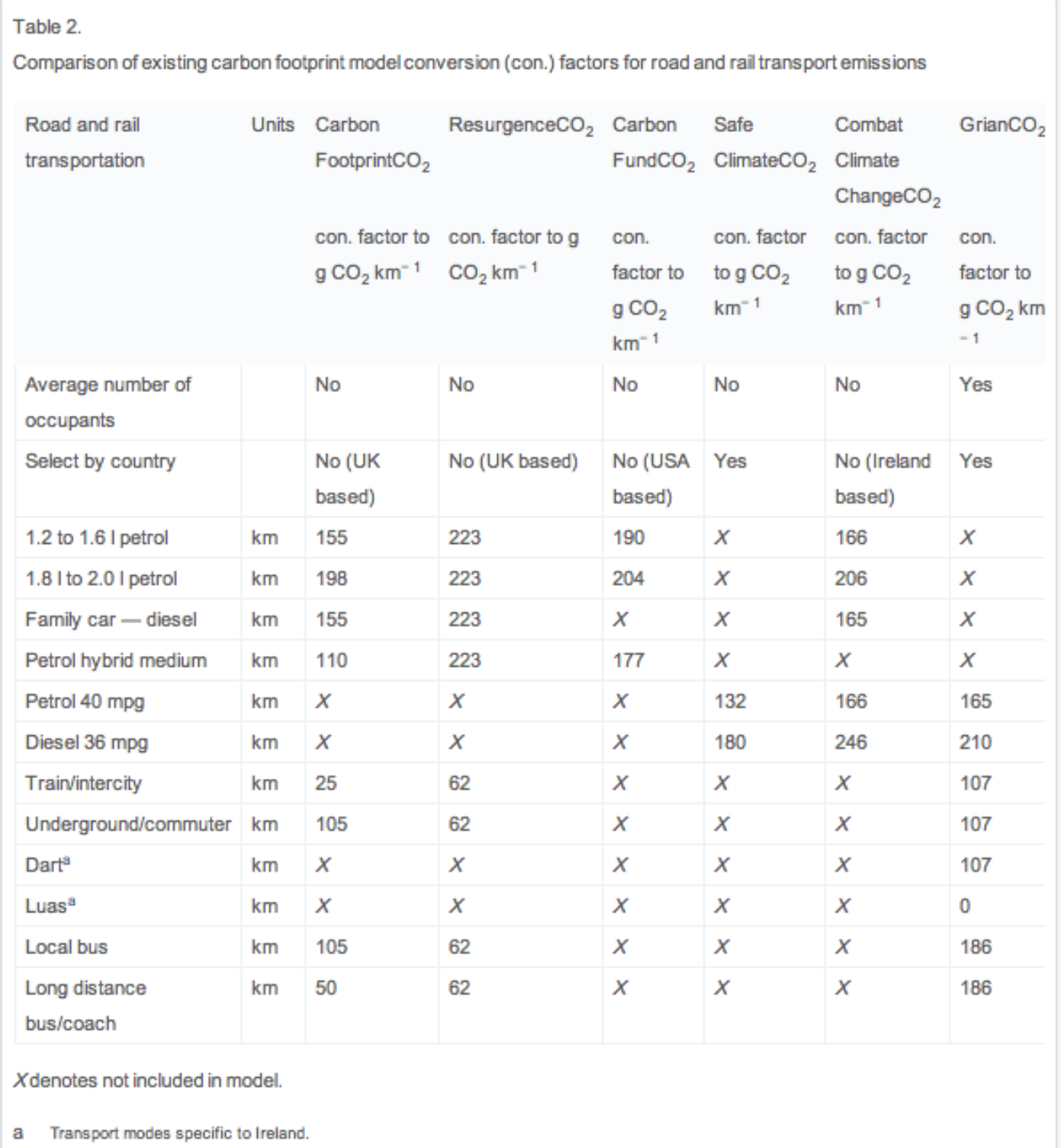


Table 3.

Table 3

Comparison of existing carbon footprint model conversion (con.) factors of fuel intensive leisure activities and flight emissions

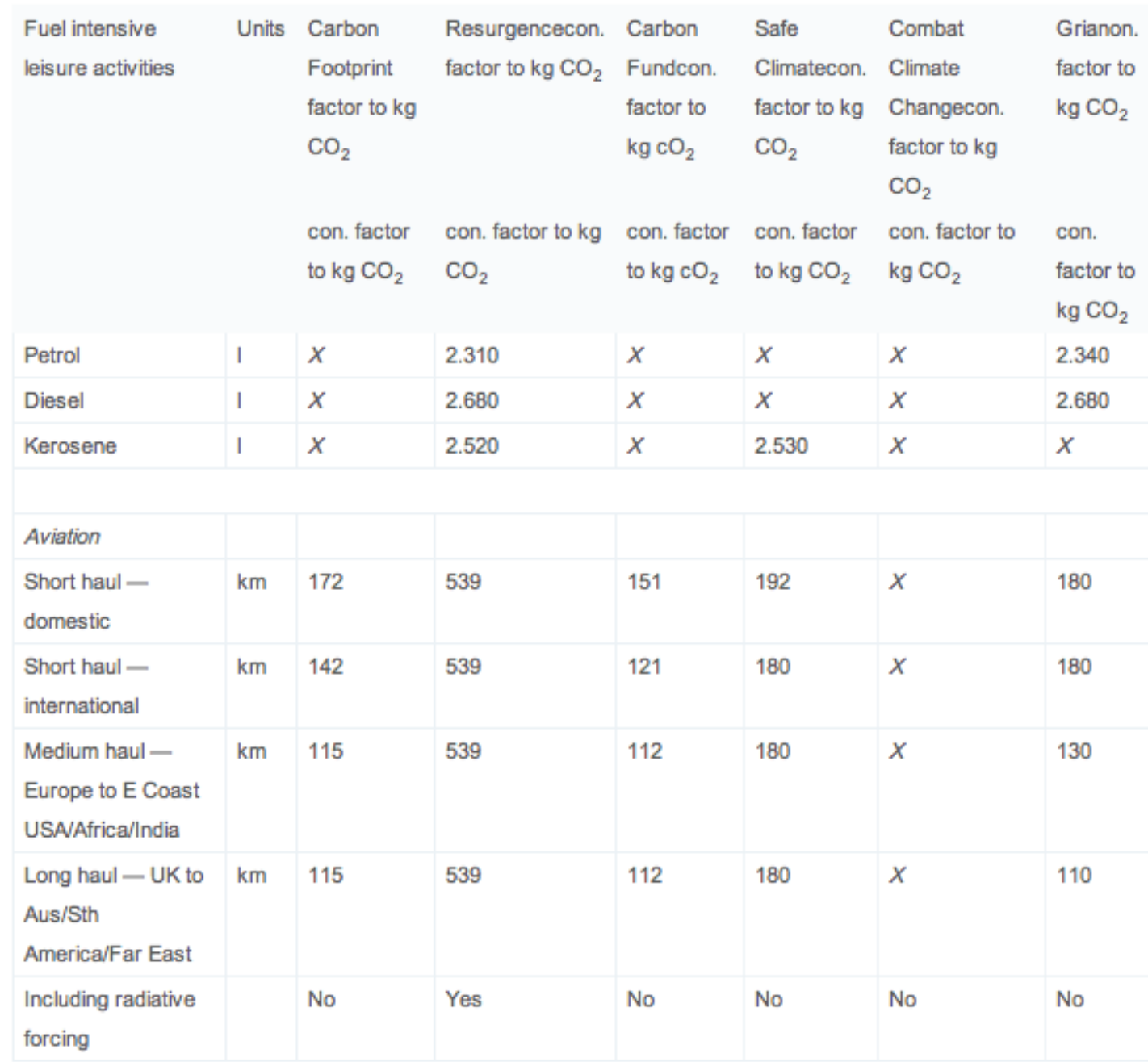

$X$ denotes not included in model.

There is a wide variation in the parameters included in each model often with significant differences in conversion factors and methods of conversion. This makes models often difficult to use and makes an accurate determination of $\mathrm{CO} 2$ emissions, due to the complexity of the unique energy use and transportation pattern of each household, extremely difficult to achieve.

\subsection{Comparative performance of selected models}

Total emissions for the household calculated by the models varied from 12,053 to 27,218 (mean 18,117) kg CO2 yr- 1 with a sample standard deviation (sd) of $5106 \mathrm{~kg}$ CO2 (Table 4). This is broken down into household energy emissions which varied from 5735 to $11,515 \mathrm{~kg}$ CO2 yr- 1 (mean $7276 \mathrm{~kg}$ CO2, sd 1966) and road transport emissions of 4805 to $6919 \mathrm{~kg} \mathrm{CO} 2 \mathrm{yr}-1$ (mean $5610 \mathrm{~kg} \mathrm{CO} 2$, 
sd 760). When aviation emissions are excluded the household and transportation emissions ranged from 10,540 to $17,361 \mathrm{~kg} \mathrm{CO} 2 \mathrm{yr}-1$ (mean $12,886 \mathrm{~kg} \mathrm{CO} 2$, sd 2134) a variation of nearly 7 tonnes between models. Padgett et al. (2008) have also reported such high variability between models. By comparing ten US CO2 models they observed variation in estimates of up to 1.8 tonnes/person/annum. In this study total emissions varied in the models accessed via the Internet from 4018 to $9073 \mathrm{~kg} \mathrm{CO} 2 \mathrm{yr}-1 /$ person, a variation of over 5 tonnes/person/annum based on a household of 3 (Table 4).

Table 4.

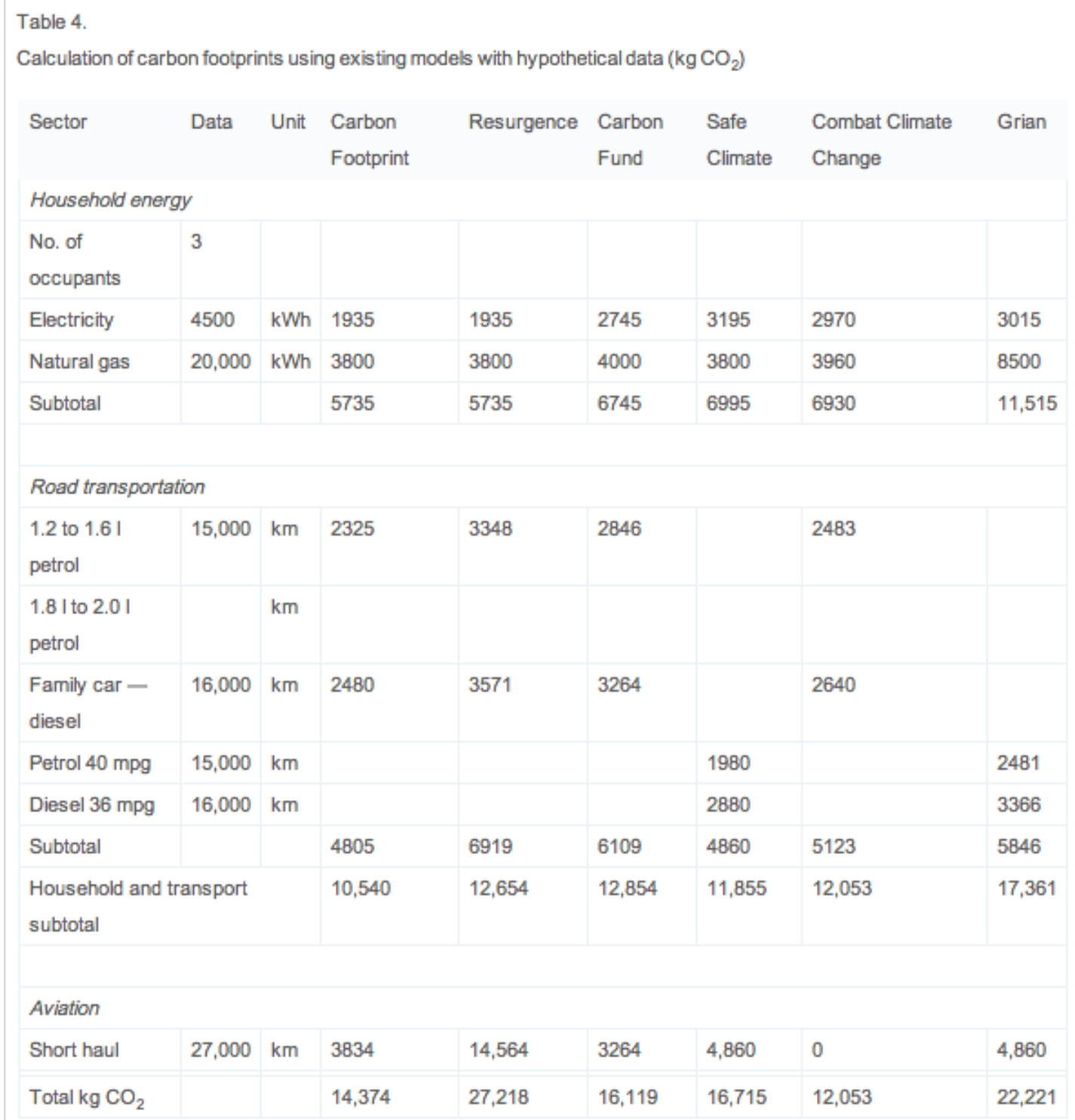

The comparatively higher emissions derived from the Resurgence and Grian models are due to an anomaly within each of these models. The multiplier of three for radiative forcing from flight emissions in Resurgence and $425 \mathrm{~g} \mathrm{CO} 2$ $\mathrm{kWh}-1$ from natural gas emissions in Grian. For comparative purposes the multiplier of three was removed from Resurgence, gas emissions from Grian were changed to a more realistic value of $198 \mathrm{~g} \mathrm{CO} 2 \mathrm{kWh}-1$. Also, $4860 \mathrm{~kg} \mathrm{CO} 2$ 
was added to Combat Climate Change to include an allowance for flights, which is absent from the original model. This reduced the variability between the models significantly with the household and transportation subtotal ranging from 10,540 to $12,854 \mathrm{~kg} \mathrm{CO} 2 \mathrm{yr}-1$ (mean 12,130, sd 805) and total emissions from 14,374 to $17,681 \mathrm{~kg} \mathrm{CO} 2 \mathrm{yr}-1$ (mean 16,552, sd 1101) (Table 5).

Table 5.

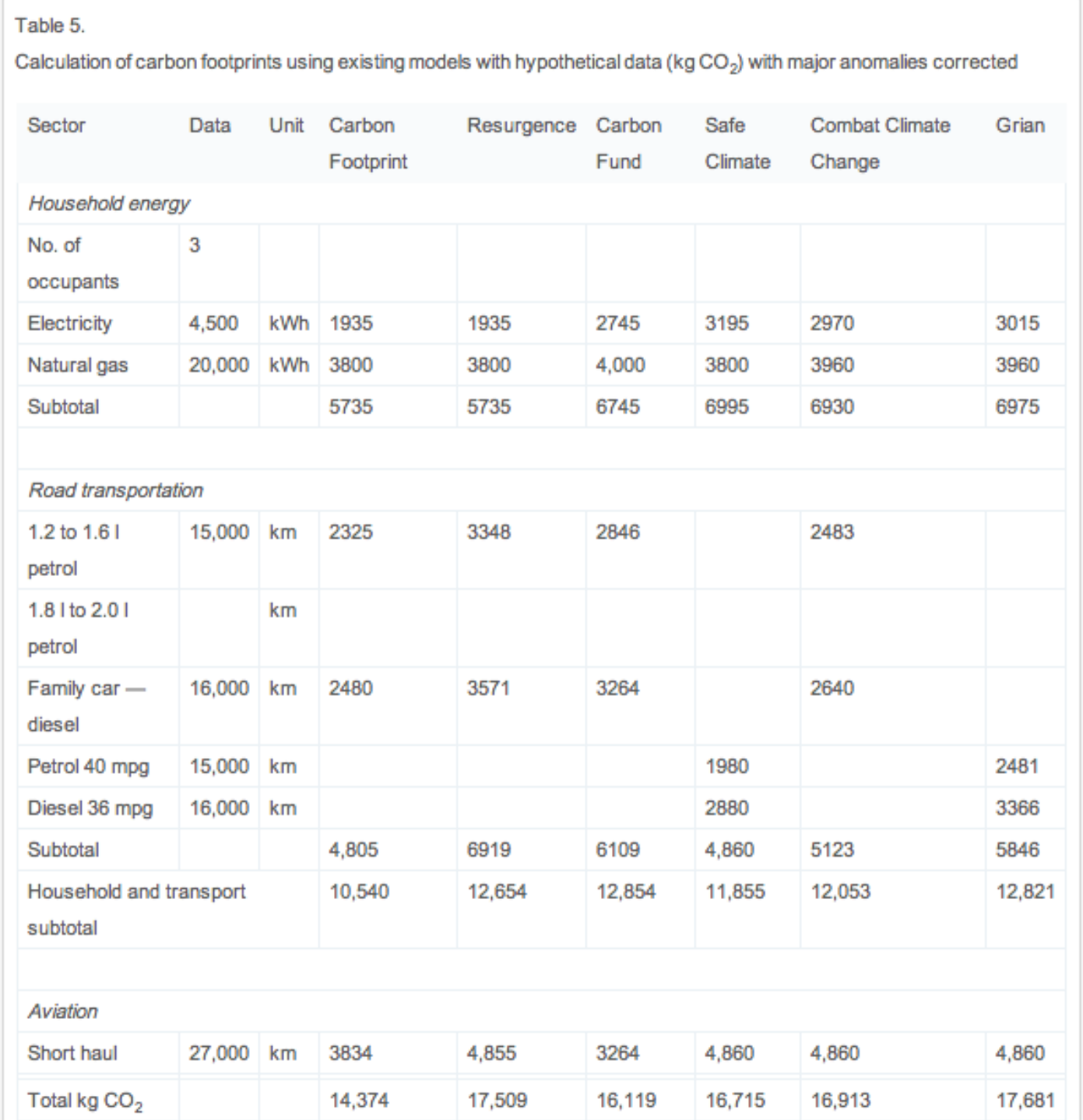

\subsection{Comparison of models using specific Irish conversion factors}

To examine the applicability of the models for use in Ireland, specific conversion factors were derived from current fuel mixes and net calorific values from a wide range of Irish sources. Conversion factors for $\mathrm{CO} 2$ and $\mathrm{CO} 2 \mathrm{e}$ emissions are summarized in Table 6 with the basic conversion factors applied. Inclusion of emission factors for $\mathrm{CH} 4$ and $\mathrm{N} 2 \mathrm{O}$ (CO2e) results in an overall increase of $1.8 \%$ on the total $\mathrm{CO} 2$ emissions. 
Table 6.

\begin{tabular}{|c|c|c|c|c|c|c|}
\hline \multicolumn{7}{|c|}{$\begin{array}{l}\text { Results of calculation of carbon footprints using current Irish conversion factors (ICFs) with hypothetical data for basid } \\
\mathrm{CO}_{2} \text { emissions }\left(\mathrm{kg} \mathrm{CO}_{2}\right) \text { and total } \mathrm{CO}_{2} \mathrm{e}\left(\mathrm{kg} \mathrm{CO}_{2} \mathrm{e}\right) \text { emissions including the contribution from other greenhouse gases }\end{array}$} \\
\hline Sector & Data & Unit & Conversion factor to $\mathrm{kg} \mathrm{CO}_{2}$ & ICFs & Conversion factor to $\mathrm{kg} \mathrm{CO}_{2} \mathrm{e}$ & ICFs \\
\hline \multicolumn{7}{|l|}{ Household energy } \\
\hline No. of occupants & 3 & & & & & \\
\hline Electricity & 4,500 & $\mathrm{kWh}$ & 0.607 & 2732 & 0.607 & 2732 \\
\hline Natural gas & 20,000 & kWh & 0.185 & 3700 & 0.187 & 3740 \\
\hline Subtotal & & & & 6432 & & 6472 \\
\hline \multicolumn{7}{|l|}{ Road transportation } \\
\hline 1.2 to 1.61 petrol & 15,000 & $\mathrm{~km}$ & 0.200 & 3000 & 0.210 & 3150 \\
\hline Family car — diesel & 16,000 & $\mathrm{~km}$ & 0.188 & 3008 & 0.192 & 3072 \\
\hline Subtotal & & & & 6008 & & 6222 \\
\hline \multicolumn{3}{|c|}{ Household and transport subtotal } & & 12,440 & & 12,694 \\
\hline \multicolumn{7}{|l|}{ Aviation } \\
\hline Short haul & 27,000 & $\mathrm{~km}$ & 0.130 & 3510 & 0.131 & 3537 \\
\hline Total kg CO 2 & & & & 15,950 & & 16,231 \\
\hline
\end{tabular}

Using the same household data the current (2007) Irish conversion factors (ICFs) were directly compared to the existing models with the anomalies corrected. As the conversion factors used in the existing models do not include $\mathrm{CH} 4$ and $\mathrm{N} 2 \mathrm{O}$ emissions, these were also excluded in the calculation of $\mathrm{CO} 2$ emissions using the ICFs to enable direct comparisons to the models to be made (Table 6). The carbon emissions for the theoretical household of three are compared to the existing adjusted model emissions (Table 7). Household energy emissions were $6432 \mathrm{~kg} \mathrm{CO} 2 \mathrm{yr}-1 \mathrm{using}$ ICFs compared to a mean of $6519 \mathrm{~kg}$ C02 yr- 1 (sd 614) generated by the six models a variation on the new Irish value of -11 to $+8 \%$ with the Caron Fund model the closest with an overestimation of 5\%. Transportation emissions based on two cars varied between 4805 and $6919 \mathrm{~kg} \mathrm{CO} 2 \mathrm{yr}-1$ with a mean of $5610 \mathrm{~kg} \mathrm{CO} 2 \mathrm{yr}-1$ (sd 833) which is almost $400 \mathrm{~kg}$ CO2 less than ICFs derived emissions at $6008 \mathrm{~kg} \mathrm{CO} 2 \mathrm{yr}-$ 1. It was in this category where the greatest variation from the Irish value was seen at -20 to $+15 \%$ with the Caron Fund model again closest with an overestimation of just $2 \%$. However, when these two sectors are combined then the calculated emissions are within 3\% of the ICFs total of 12,440 kg CO2 for three models, Resurgence (2\%); Carbon Fund (3\%) and Combat Climate Change $(-3 \%)$. Emissions from aviation calculated using ICFs are $912 \mathrm{~kg} \mathrm{CO} 2$ less at $3510 \mathrm{~kg} \mathrm{CO} 2 \mathrm{yr}-1$ for the household compared to the mean of $4422 \mathrm{~kg} \mathrm{CO} 2 \mathrm{yr}-$ 1 (sd 700) for the models with a variation of -7 to $+38 \%$ over the Irish value with the Carbon Fund model closest with an underestimation of $7 \%$. The total annual emissions from the household measured using ICFs are some $600 \mathrm{~kg}$ less 
than the mean of the models at $15,950 \mathrm{~kg} \mathrm{CO} 2 \mathrm{yr}-1$, a variation of -10 to $+11 \%$, with the Carbon Fund and Safe Climate models closest with overestimations of < $5 \%$.

Table 7.

\begin{tabular}{|c|c|c|c|c|c|c|c|}
\hline \multicolumn{8}{|c|}{$\begin{array}{l}\text { Comparison of carbon footprints as measured using current Irish conversion factors (ICFs) and existing (adjusted) } \\
\text { models using hypothetical household data }\left(\mathrm{kgCO}_{2}\right)\end{array}$} \\
\hline \multirow[t]{2}{*}{ Sector } & Carbon & Resurgence & Carbon & Safe & Combat Climate & Grian & ICFs \\
\hline & Footprint & & Fund & Climate & Change & & \\
\hline \multicolumn{8}{|l|}{ Household energy } \\
\hline No. of occupants & UK & UK & USA & Ireland & Ireland & Ireland & Ireland \\
\hline Electricity & 1935 & 1935 & 2745 & 3195 & 2970 & 3015 & 2732 \\
\hline Natural gas & 3800 & 3800 & 4,000 & 3800 & 3960 & 3960 & 3700 \\
\hline Subtotal & 5735 & 5735 & 6745 & 6995 & 6930 & 6975 & 6432 \\
\hline$\%$ difference to ICFs & $-11 \%$ & $-11 \%$ & $5 \%$ & $9 \%$ & $8 \%$ & $8 \%$ & \\
\hline \multicolumn{8}{|l|}{ Road transportation } \\
\hline 1.2 to 1.6 I petrol & 2325 & 3348 & 2846 & & 2483 & & 3000 \\
\hline $1.8 \mathrm{I}$ to $2.0 \mathrm{I}$ petrol & & & 3264 & & & & \\
\hline Family car — diesel & 2480 & 3571 & & & 2640 & & 3008 \\
\hline Petrol 40 mpg & & & & 1980 & & 2481 & \\
\hline Diesel 36 mpg & & & & 2880 & & 3366 & \\
\hline Subtotal & 4,805 & 6919 & 6109 & 4,860 & 5123 & 5846 & 6008 \\
\hline \% difference to ICFs & $-20 \%$ & $15 \%$ & $2 \%$ & $-19 \%$ & $-15 \%$ & $-3 \%$ & \\
\hline $\begin{array}{l}\text { Household and transport } \\
\text { subtotal }\end{array}$ & 10,540 & 12,654 & 12,854 & 11,855 & 12,053 & 12,821 & 12,440 \\
\hline$\%$ difference to ICFs & $-15 \%$ & $2 \%$ & $3 \%$ & $-5 \%$ & $-3 \%$ & $3 \%$ & \\
\hline \multicolumn{8}{|l|}{ Aviation } \\
\hline $\begin{array}{l}\text { Short haul - } \\
\text { international }\end{array}$ & 3834 & 4,855 & 3264 & 4,860 & 4,860 & 4,860 & 3510 \\
\hline$\%$ difference to ICFs & $9 \%$ & $38 \%$ & $-7 \%$ & $38 \%$ & $38 \%$ & $38 \%$ & \\
\hline Total kg CO & 14,374 & 17,509 & 16,119 & 16,715 & 16,913 & 17,681 & 15,950 \\
\hline$\%$ difference to ICFs & $-10 \%$ & $10 \%$ & $1 \%$ & $5 \%$ & $6 \%$ & $11 \%$ & \\
\hline
\end{tabular}

Variation of models from ICFs values are given as a percentage.

Thus using the best carbon footprint models available on the Internet to calculate the $\mathrm{CO} 2$ emissions from the hypothetical Irish household, emissions can be either underestimated or overestimated by approximately $10 \%$ and this is after certain adjustments were made to three of the calculators to reduce this 
variability due to calculation errors. This also excludes emissions from $\mathrm{CH} 4$ and N20.

However, while the analysis of household carbon footprints is currently the most appropriate and relevant method of assessing household consumption in terms of energy and fuel use, they do not currently take into account input and output analysis of other materials including food, clothes, household goods, pharmaceutical and personal care products (PPCPs), services etc. (Peters and Hertwich, 2006 and Wiedmann et al., 2007). Due to increased international trade much of this portion of household CO2 input occurs outside the country. Weber and Matthews (2008) estimate that as much as 30\% of total US household CO2 released occurred outside the US in 2004. Many of these factors are within the control of individuals, especially household waste production, and should be taken into account within household carbon dioxide emission models.

\subsection{Specific issues relating to Ireland}

The main difference between the electricity supply in Ireland compared with that of the UK or USA is that the latter use nuclear power resulting in substantially less oil and peat in their fuel mixes. The average $\mathrm{CO} 2$ emission from electricity in the UK is $461 \mathrm{~g} / \mathrm{kWh}$ (Electricity Information, 2007) compared to $430 \mathrm{~g} / \mathrm{kWh}$ that is used in the UK models. In Ireland the conversion factor for electricity is considerably higher at $607 \mathrm{~g} / \mathrm{kWh}$ although the Safe Climate, Combat Climate Change and Grian models all appear to be using information relating to older fuel mixes (Table 6). The current Irish conversion factor used here for natural gas takes into account the increasing contribution of imported gas, currently at $87 \%$ of the total, which is more carbon intensive (EPA, 2007b). This gives a current Irish conversion factor of $185 \mathrm{~g} / \mathrm{kWh}$ which is overestimated by the Irish models studied. In the UK the recommended conversion rate for natural gas has risen from $190 \mathrm{~g} / \mathrm{kWh}$ in 2005 to $206 \mathrm{~g} / \mathrm{kWh}$ in 2007 due to the percentage of imported gas ( Defra, 2005, Defra, 2007a, Defra, 2007b and Defra, 2007c). Not all carbon footprint models incorporate CO2 emissions from LPG (Table 1). The current Irish conversion factor is calculated as $1.52 \mathrm{~kg} \mathrm{CO} 2 \mathrm{l}-1$, which is almost identical to the Defra value of $1.49 \mathrm{~kg} \mathrm{CO} 2 \mathrm{l}-1$ ( Defra, 2005, Defra, 2007a, Defra, 2007b and Defra, 2007c). The current Irish conversion factor for oil is $2.70 \mathrm{~kg} \mathrm{CO} 2 \mathrm{l}-1$ of fuel just $0.01 \mathrm{~kg} \mathrm{CO} 2 \mathrm{l}-1$ less than the factor used in the Carbon Footprint model of $2.69 \mathrm{~kg}$ CO2 $\mathrm{l}-1$ recommended by Defra (2005). The Safe Climate model overestimates the CO2 emissions from oil consumed in Ireland by $16 \%$.

The models compared all indicate different levels of $\mathrm{CO} 2$ emissions from coal. The Carbon Footprint model at $2.55 \mathrm{~kg} \mathrm{CO} 2 \mathrm{~kg}-1$ complies with the emission factor for coal supplied by Defra (2005), although this would appear to be an average for bitumous and anthracite coal. Resurgence and Safe Climate seem to be based on emissions from bitumous coal only and Combat Climate Change 
from anthracite. Bitumous coal is not for sale in Dublin but the smokeless coal anthracite is available for modified stoves and boilers only. Combat Climate Change is the only model that incorporates emissions from turf peat and briquettes. Peat remains a major household fuel in Ireland and is used in two forms. Traditional sod peat (turf) is raw peat that has been hand dug, while peat briquettes are comprised of finely milled peat that has been mechanically pressed into rectangular blocks. The net calorific value of Irish sod peat is 13.105 compared to $18.548 \mathrm{MJ} / \mathrm{kg}$ for peat briquettes ( SEI, 2006 and IMCG, 2007) from which the CO2 emissions/kg can be calculated as 1.377 and $1.852 \mathrm{~kg} \mathrm{CO} 2 \mathrm{~kg}-1$ respectively. The conversion factor of $1.362 \mathrm{~kg} \mathrm{CO} 2$ used by Combat Climate Change is comparable with the calculated value obtained from base Irish data (EPA, 2006). However, the emissions of $1.839 \mathrm{~kg} \mathrm{CO} 2 / \mathrm{bale}$ of briquettes must be an error and should relate to emissions $/ \mathrm{kg}$, which is similar to $1.852 \mathrm{~kg} \mathrm{CO} 2$ calculated in this study. The average weight of a bale of briquettes is $12 \mathrm{~kg}$ resulting in $22.224 \mathrm{~kg}$ of $\mathrm{CO} 2$ released per bale burnt, with higher $\mathrm{CO} 2 \mathrm{e}$ emissions than sod peat for both $\mathrm{CH} 4$ and $\mathrm{N} 20$ at 0.256 and $0.329 \mathrm{~kg}$ respectively per bale.

The $\mathrm{CO} 2$ emissions from biomass (wood products) combustion are not included in national totals (IPPC, 2006). This approach assumes that all wood products come from a renewable and sustainable source; that for every tree cut down and burnt a new tree is planted in its place. However, this does not take into account of non-recyclable GHG emissions of $\mathrm{CH} 4$ and N2O which were calculated in this study as 0.108 and $0.019 \mathrm{~kg}$ CO2e kg- 1 respectively.

\section{Conclusions}

The information provided by these widely used carbon footprint models are inconsistent and often contradictory. There are no standards available in relation to where the emission factors are sourced or for what fuels and activities each model should cover resulting in anomalies. To enable individuals to calculate their carbon dioxide emissions accurately information should come from a credible and regularly updated source, be transparent and country specific. All transportation, energy and fuel types need to be available as options within models, and these vary significantly between countries. Internet models do not include data on other greenhouse gases such as CH4 and N2O that leads to a small, but potentially significant, underestimation of emissions in terms of carbon dioxide equivalents ( $\mathrm{CO} 2 \mathrm{e}$ ). Currently available models provide estimates rather than accurate measures of $\mathrm{CO} 2$ emissions. There is an urgent need for comprehensive and reliable models that can accurately determine individual and household primary carbon footprints.

\section{References}

Bin and Dowlatabadi, 2005 
S. Bin, H. Dowlatabadi

Consumer lifestyle approach to US energy use and the related CO2 emissions

Energy Policy, 33 (2005), pp. 197-208

Bows et al., 2006

A. Bows, S. Mander, R. Starkey, M. Bleda, K. Anderson

Living within a carbon budget. Tyndall Centre

University of Manchester, Manchester (2006)

http://www.foe.co.uk/resource/reports/living_carbon_budget.pdf (accessed 16 March '07)

CEC, 2005

CEC

Winning the Battle against Global Climate Change. Communication from the Commission to the Council, the European Parliament, the European Economics and Social Committee and the Committee of the Regions. COM (2005)35 Final

Commission of the European Communities, Brussels (2005)

CSO, 2007

CSO, (2007) Irish Census data 2006. http://www.cso.ie/census/(accessed 8 September 2007).

Defra, 2005

Defra

Guidelines for Company Reporting on Greenhouse Gas Emissions Annexes updated July 2005

UK Department for Environment, Food and Rural Affairs, London (2005) http://www.defra.gov.uk/environment/business/envrp/pdf/envrpgasannexes.pdf. (accessed 29 June 2007).

Defra, 2007a

Defra

Guidelines to DEFRA's greenhouse gas (GHG) conversion factors for company reporting - June 2007 
UK Department for Environment, Food and Rural Affairs, London (2007) http://www.defra.gov.uk/environment/business/envrp/pdf/conversionfactors.pdf (accessed 29 June 2007).

Defra, 2007b

Defra

Passenger transport emissions factors: Methodology paper — June 2007

UK Department for Environment, Food and Rural Affairs, London (2007) http://www.defra.gov.uk/environment/business/envrp/pdf/passengertransport.pdf (accessed 2 July 2007).

Defra, 2007c

Defra

UK Greenhouse Gas Inventory 1990 to 2005: Annual Report for submission under the Framework Convention on Climate Change - April 2007

UK Department for Environment, Food and Rural Affairs, London (2007) http://www.airquality.co.uk/archive/reports/cat07/0704261626_ukghgi-9005_main_chapters_final.pdf (accessed 2 July 2007)

Dukes, 2006

Dukes

Digest of United Kingdom Energy Statistics

(2006) http://stats.berr.gov.uk/energystats/dukes06.pdf (accessed 2 July 2007). Electricity Information, (2007) http://www.electicityinfo.org (accessed 18 July 2007)

EPA, 2006

EPA

Implications of the EU Climate Protection Target for Ireland. Environmental Protection Agency

Johnstown Castle, Wexford (2006) http://www.epa.ie/downloads/pubs/research/climate/erc\%20report\%205.pdf (accessed 21 September 2007). 
EPA, 2007a

EPA

EPA: 2020 Vision — Protecting and Improving Ireland's Environment.

Environmental Protection Agency

Johnstown Castle, Wexford (2007)

http://www.epa.ie/downloads/pubs/other/corporate/2020\%20vision.pdf (accessed 20 June 2007)

EPA, 2007b

EPA

National Inventory Report 2007: Greenhouse Gas Emissions 1990-2005

Reported to the United Nations Framework Convention on Climate Change

(2007) http://coe.epa.ie/ghg/nirs/NIR_2007_IE.pdf (accessed 29 June 2007)

Forster et al., 2006

P.M.D.F. Forster, K.P. Shine, N. Stuber

It is premature to include non-CO2 effects of aviation in emission trading schemes.

Atmos. Environ., 40 (2006), pp. 1117-1121

Article | PDF (162 K) | View Record in Scopus | Cited By in Scopus (42)

IMCG, 2007

IMCG

The CO2 emission factor of peat fuel. International Mire Conservation Group (2007) http://www.imcg.net/imcgnl/nl0702/kap05.htm (accessed 10 July 2007)

IPCC, 2006

IPCC, (2006) 2006 IPCC Guidelines for National Greenhouse Gas Inventories. Volume 2 - Energy. Chapter 1 - Introduction. http://www.ipccnggip.iges.or.jp/public/2006gl/pdf/2_Volume2/V2_1_Ch1_Introduction.pdf (accessed 8 July 2007).

IPCC, 2007 
IPCC

Climate Change 2007: The Physical Science Basis - Summary for Policy Makers (2007) http://www.ipcc.ch/SPM2feb07.pdf (accessed 20 March '07).

Lynas, 2007

M. Lynas

Carbon Counter

HarperCollins Publishers, Glasgow (2007)

Meinshausen, 2005

M. Meinshausen

On the Risk of Overshooting $2{ }^{\circ}$ C. Paper presentedat Scientific Symposium Avoiding Dangerous Climate Change. 1-3 February 2005

Meteorological Office, Exeter (2005)

O'Donoghue, 1997

C. O'Donoghue

Carbon Dioxide, Energy Taxes and Household Income

The Economic and Social Research Institute, Dublin (1997)

Padgett et al., 2008

J.P. Padgett, A.C. Steinemann, J.H. Clarke, M.P. Vandenbergh

A comparison of carbon calculators

Environ. Impact. Assess. Rev. (2008)

http://dx.doi.org/10.1016/j.eiar.2007.08.001

Peters and Hertwich, 2006

G.P. Peters, E.G. Hertwich

The importance of imports for household environmental impacts

J. Ind. Ecol., 10 (2006), pp. 89-109 
SEI, 2006

SEI

Energy Statistics 1990-2005

(2006) http://www.sei.ie/index.asp?locID=686\&docID=659 (accessed 18 July 2007)

Stern, 2006

N. Stern

Stern Review: The Economics of Climate Change

HM Treasury, London (2006)

http://www.hmtreasury.gov.uk/independent_reviews/stern_review_economics_ climate_change/stern_review_report.cfm (accessed 20 March 2007)

Tukker and Jansen, , 2006

A. Tukker, B. Jansen

Environmental impacts of products - a detailed review of studies

J. Ind. Ecol., 10 (2006), pp. 159-182

Weber and Matthews, , 2008

C.L. Weber, H.S. Matthews

Quantifying the global and distributional aspects of American household carbon footprint

Ecol Econ (2008) http://dx.doi.org/10.1016/j.ecolecon.2007.09.021

Wiedmann et al., 2007

T. Wiedmann, M. Lenzen, K. Turner, J. Barrett

Examining the global environmental impact of regional consumption activities part 2: review of input-output models for the assessment of environmental impacts embodied in trade

Ecol Econ, 61 (2007), pp. 15-26 
World Resource Institute, 2007

World Resource Institute

CO2 Emissions: CO2 emissions per capita

(2007) http://www.earthtrends.wri.org (accessed 5 July 2007) 